Електронне наукове фахове видання з економічних наук «Modern Economics», №21 (2020), 6-12 https://modecon.mnau.edu.ua | ISSN 2521-6392

JEL Classification: G30; G32; G39

DOI: https://doi.org/10.31521/modecon.V21(2020)-01

\author{
Aleksin Glib, Postgraduate, Institute for Economics and Forecasting, NAS Ukraine, Kyiv, Ukraine \\ ORCID ID: 0000-0003-2586-5986 \\ e-mail: gleb.aleksin@gmail.com
}

\title{
Company Financial Strategy`s Essence and Its Components
}

Abstract. Introduction. Current conditions of economic activity create a number of challenges for companies, i.e. macroeconomic shocks, external environment's increasing uncertainty, global competitive environment intensification, other factors of endogenous and exogenous environment. All above mentioned requires business leaders to strengthen strategic management system in all aspects of doing business in order to compete for limited resources in more effective ways. Company's effective strategic management system, including strategic management of company's finance, should serve the ultimate goal for a company, namely added value creation for stakeholders. In light of this, there is an urgent need for an in-depth understanding of financial strategy's essence and its components.

Purpose. Paper's objective is to generalize theoretical foundations of "company's financial strategy" concept and substantiate proposals for improving "company`s financial strategy" definition and identify components of company`s financial strategy.

Results. The article considers company's financial strategy essence and its components. Author proposed to define "company`s financial strategy" in a broad and narrow sense. In a narrow sense, it is proposed to consider financial strategy as a set of managerial decisions aimed at capital structure optimizing and minimizing WACC in order to create value added for stakeholders. In a broad sense, it is proposed to consider financial strategy as a set of managerial decisions within strategic financial management framework of funding policy, investment policy and dividend policy, contributing to sustainable competitive advantages' maintenance, optimizing capital structure, market capitalization growth and value added creation for stakeholders. Paper considers an array of works of Ukrainian and foreign researchers in the field of financial strategy and strategic financial management in order to identify areas for improvement of "financial strategy of the enterprise" definition. Author proposed to consider financial strategy as a cross-disciplinary concept that lies between corporate finance theory and strategic management theory. Author proposed to further consider financial strategy through its signaling function. Paper considers financial strategy in the context of financial management decisions' value-chain, namely decisions on funding, investment and dividends distribution. Author emphasizes a need to consider financial strategy in the context of a company's strategic goals, which is expressed in both financial and non-financial purposes. It is proposed to consider financial strategy as a mediator between corporate strategy, functional strategies, company's contour of financial communication to external and internal stakeholders. The complex of financial strategy within the stakeholders'value-chain is outlined.

Conclusions. Financial strategy aims to achieve both general market and specific financial goals. Being a crossdisciplinary concept (i.e., corporate finance theory - strategic management theory), a balanced financial strategy should take into account interests of all external and internal stakeholders, namely: employees, company's management, government, creditors, suppliers, local community, consumers, and others. Creating value for shareholders and other stakeholders is possible as a result of financial decisions' implementation in the following areas: 1. determining an optimal capital structure and raising funds at the lowest possible cost; 2. sound investment policy and efficient allocation of internal resources; 3 . dividend policy and Investor Relations. Such a set of objectives entails a need for financial strategy - at its formation and implementation stages - to consider not only company's financial perspective, but also the overall company's interaction with both internal and internal environment. Accordingly, development of financial managerial decisions requires considering potential consequences for stakeholder groups (entailing behaviorism aspects, rational and irrational motivations). Thus, an effective and efficient financial strategy is a complex multi-level cross-disciplinary concept that takes into account both narrow tasks (capital structure optimization) and broad tasks (strengthening company`s long-term market position, creating added value for stakeholders), which should be based not only on the analysis of retrospective financial and management accounting data, but also consider scientific and practical developments, which, as a result, forms an effective and balanced financial and corporate strategy for a company.

Keywords: financial strategy; capital structure; value added; stakeholder; funding policy; investment policy; dividend policy.

\section{УДК 336.64}

Алексін Г. о., аспірант, Інститут економіки та прогнозування, НАН України, м. Київ, Україна

\section{Сутність фінансової стратегії підприємств та їі складові}

Анотація. У статті розглянуто питання сутності фінансової стратегї̈ підприємств та ї̈ складові. Запропоновано визначати поняття «фінансова стратегія підприємства» в широкому та вузькому розумінні. У вузькому розумінні пропонується розглядати фінансову стратегію підприємства як комплекс управлінських рішень, направлених на оптимізацію структури капіталу та мінімізацію його середньозважених затрат з метою створення вартості для стейкхолдерів. У широкому розумінні пропонується розглядати фінансову стратегію підприємства як комплекс управлінських рішень стратегічного фінансового управління в рамках політики фінансування, інвестиційної

Стаття надійшла до редакції: 10.06 .2020

Received: 10 June 2020 
політики та дивідендної політики, що сприяють встановленню стійких конкурентних переваг, оптимізації структури капіталу, росту ринкової капіталізації та створення доданої вартості для стейкхолдерів. У статті розглянуто масив праць українських і зарубіжних дослідників з напряму фінансової стратегії та стратегічного фінансового управління з метою виявлення зон для вдосконалення визначення «фінансова стратегія підприємства». Запропоновано розглядати фінансову стратегію як крос-дисциплінарне поняття, що знаходиться між площинами теорії корпоративних фінансів i теорії стратегічного управління. Запропоновано додатково розглядати фінансову стратегію через їі сигнальну функцію. У статті фінансова стратегія розглядається в контексті ланцюгу створення доданої вартості для стейкхолдерів за рахунок фінансових управлінських рішень, а саме рішень щодо фінансування, інвестування та виплати дивідендів. Наголошено на необхідності розгляду фінансової стратегії в контексті стратегічних цілей підприємства, що виражається як у фінансових, так і нефінансових цілях. Фінансову стратегію запропоновано розглядати як медіатор між корпоративною стратегією, функціональними стратегіями, контуром фінансової комунікації підприємства зовнішнім і внутрішнім стейкхолдерам. Окреслено комплекс фінансової стратегії підприємства в рамках ланцюгу створення доданої вартості для стейкхолдерів.

Ключові слова: фінансова стратегія; структура капіталу; додана вартість; стейкхолдер; політика фінансування; інвестиційна політика; дивідендна політика.

Problem setting. Current conditions of economic activity create a number of challenges for companies, i.e. macroeconomic shocks, external environment's increasing uncertainty, global competitive environment intensification, other factors of endogenous and exogenous environment. All above mentioned requires business leaders to strengthen strategic management system in all aspects of doing business in order to compete for limited resources in more effective ways. Company's effective strategic management system, including strategic management of company `s finance, should serve a company`s ultimate goal, namely added value creation for stakeholders. In light of this, there is an urgent need for an in-depth understanding of financial strategy's essence and its components.

Recent research and publications analysis. Company's financial strategy is studied in numerous papers by both Ukrainian and foreign researchers, namely R. Ackoff, I. Ansoff, D. Arutyunova, K. Bender, M. Bilyk, I. Blank, E. Brigham, A. Chandler, D. Cleland, N. Gorytska, I. Ivashkovska, B. Karlof, A. Podderyogin, A. Polchanov, M. Porter, A. Semenov, T. Teplova, O. Tereshchenko and others.

Research objective. Paper's objective is to generalize theoretical foundations of "company's financial strategy" concept and substantiate proposals for improving "company`s financial strategy" definition and identify components of company`s financial strategy.

Results and discussion. Company is unable to achieve its market goals without a well-established process of developing and implementing its strategy. Financial strategy is one of the key components of company's strategy system. Strategy's successful implementation is impossible without coordination of all its components, namely company's functional strategies (marketing strategy, operational strategy, R\&D strategy, etc.) and their coordination with company`s financial strategy.

Uncertainty, which exhibits itself in a global recession `s growing likelihood, trade wars` intensification among major national economies, political instability in different regions, and specifically in Ukraine - in a form of socio-economic and financial crisis - requires from companies new non-standard approaches towards developing and implementing financial strategy. In terms of financial strategy planning, there has been a shift in priorities: in the context of significant reductions in demand, closure of traditional export markets, macroeconomic shocks and increasing uncertainty, company's management should shift its focus towards company`s survival, market position maintenance under squeezed financing, business activity level maintenance under households' declining purchasing power. In terms of financial strategy's, implementing constraints created by modern realities should be accounted for, namely: limited loan financing, constrained access to foreign financial market platforms (for fund raising purpose), underdeveloped domestic stock market, squeezed domestic demand, limited options for growth inside Ukraine, etc.

All above mentioned indicates versatility of "financial strategy" concept and the wide range of tasks faced by company`s financial strategy. That leads to an expansion of "financial strategy" definition and, as a result, to differences in its interpretation. For this reason, we compiled a table with "company's financial strategy" concept interpretations by selected Ukrainian and foreign researchers (table 1 ).

It should be noted that in the American and European literature in the field of corporate finance, "financial strategy" concept is absent. In strategic management scientific schools, formed in the XX century in Western block states, financial strategy is considered as one of the functional strategies, and scholars of corporate finance schools from these states operate with specific terms such as "capital structure", "funding policy", "long-term investment decisions", "dividend policy", "cash flow management", "financial planning", etc. In turn, Ukrainian literature, in addition to "financial strategy" concept, multiplied definitions, such as "financial policy", "financing policy", "financing strategy", "strategic financial management", "strategic financial management", etc. In a search for a rational explanation, we cite paper by Yu. Naumova [13], namely "financial strategy" concept is further specified by researchers depending on objectives of their further studies. Yu. Naumova noted also that financial strategy`s components is a debatable issue - which further multiplies "financial strategy" interpretation. In particular, R. Bender and 
Електронне наукове фахове видання з економічних наук «Modern Economics», №2 1 (2020), 6-12 https://modecon.mnau.edu.ua | ISSN 2521-6392

K. Ward identify financial strategy`s two components, i.e. resources`effective formation of needed by a company, and resources 'effective use. This point of view is formed on the basis of the reproducible concept of finance, which is quite common in Western economic thought [13].

Table 1. Analysis of interpretation of "company`s financial strategy" concept in the literature

\begin{tabular}{|c|c|}
\hline Researcher & Definition \\
\hline Ansoff I. & Defines company`s financial strategy as a complex management of all company`s assets and liabilities. \\
\hline Arutyunova D. & $\begin{array}{l}\text { Financial strategy is a long-term program of action to implement the concept of using own and borrowed } \\
\text { financial resources in order to achieve competitive advantage; through financial strategy there is an } \\
\text { integration of all specialized strategies and strategic positions into a single corporate strategy. }\end{array}$ \\
\hline $\begin{array}{l}\text { Bender K., } \\
\text { Ward R. }\end{array}$ & $\begin{array}{l}\text { Financial strategy is a management system that combines raising funding required by a company in the most } \\
\text { appropriate way and use of the raised funding, including decisions on reinvestment and distribution of profits } \\
\text { generated in subsequent periods. }\end{array}$ \\
\hline Bilyk M. & $\begin{array}{l}\text { Financial strategy is a tool for long-term management of all financial activities of a company, which are } \\
\text { subject to the company's development goals in the face of significant changes in macroeconomic } \\
\text { environment, system of state regulation of market processes, financial market conditions and subsequent } \\
\text { uncertainty. }\end{array}$ \\
\hline Blank I. & $\begin{array}{l}\text { Financial strategy is one of the major types of company`s functional strategies which supports s financial } \\
\text { activity and financial relations through formation of the long-term financial objectives, choosing the most } \\
\text { effective ways of its`achievement under evolving external environment. }\end{array}$ \\
\hline Brigham E. & $\begin{array}{l}\text { Strategic financial management is a set of managerial financial decisions harmonizing individual } \\
\text { (stakeholder) goals and company`s goals. }\end{array}$ \\
\hline Chandler A. & $\begin{array}{l}\text { Financial strategy is the definition of major long-term financial goals and company`s objectives, maintenance } \\
\text { of that course of action, allocation of resources needed to achieve those goals. }\end{array}$ \\
\hline Gorytska N. & $\begin{array}{l}\text { Financial strategy is a company`s general action plan, which covers the company`s finance formation and its } \\
\text { planning aimed at ensuring the company`s financial stability. }\end{array}$ \\
\hline Podderyogin A. & $\begin{array}{l}\text { Financial strategy is a strategy that includes methods and practices of financial resources` formation, its } \\
\text { planning and ensuring company`s financial stability under market economy conditions. }\end{array}$ \\
\hline Polchanov A. & $\begin{array}{l}\text { Financial strategy is a concept of management in the field of formation, distribution and use of company`s } \\
\text { financial resources, aimed at achieving company`s goals. }\end{array}$ \\
\hline Semenov A. & $\begin{array}{l}\text { Financial strategy is a general action plan to provide company with cash; special attention in financial } \\
\text { strategy development is given to income generation, internal resources` mobilization, production costs` } \\
\text { maximum possible reduction, proper distribution and use of profit, determining a need for working capital, } \\
\text { rational use of capital. }\end{array}$ \\
\hline
\end{tabular}

Sources: compiled by author from [1-8, 14-15, 18]

In turn, we further explain the discrepancy in "financial strategy" concept's interpretation and existence of numerous concepts bordering on "financial strategy" concept in Ukrainian studies - in contrast to studies of developed countries - due to Ukrainian realities of stakeholders ' distorted motivations (operating inside and outside a company), a company often has long-term financial and non-financial goals that partially or completely contradict a company's major objective, namely stakeholder value added creation, - where under "stakeholders" we mean not only shareholders and state and local budgets, yet broad groups of stakeholders (employees, suppliers, consumers, creditors, local community, others). Thus, if the shareholder or the state sets itself a task of leaching value from a company, which economists-practitioners from developed countries characterize as "increasing one's wealth through a company`s cash flow, yet not market capitalization", then the contour of determining and achieving these long-term financial and non-financial goals - which in essence is a company`s financial strategy - will be significantly blurred.

Discussion concerning "financial strategy" concept is further fueled by cross-disciplinary nature of company's financial strategy, i.e. concept's position between corporate finance theory and strategic management theory. In particular, S. Myers in paper [11] states that strategic management differs from corporate finance theory's postulates:

- company`s management is often more concerned with strategic managerial decisions ' impact on EPS, rather than book value, i.e. if company's managers are convinced that strategic plans add shareholder value, its impact on balance sheet indicators would be irrelevant for them;

- in some cases, company's managers seek diversification in order to reduce the degree of risk - as for investors, diversification is a far easier process due to opportunities with stock market; however, corporate diversification is a much harder task.

Discussions also arise due to a misinterpretation of the Modigliani-Miller Theorem, namely there is an opinion that financial strategy does not create value added for shareholders [11]. However, this statement does not consider the fact that capital markets are not homogeneous, and the information is unevenly distributed among these markets. The study [16] argues that the smaller the capital market, and the deeper its degree of administrative regulation, the more important is the aspect of sound financial management in the 
process of raising capital. That enhances financial strategy`s role in company`s management and corporate strategy implementation. From that we draw a conclusion on financial strategy's signaling function, which is absent in studied Ukrainian papers on "financial strategy" concept. Namely, financial strategy creates signals for internal and external stakeholders on company's medium- and long-term development direction. In practice, signals' communication takes place through a set of managerial decisions on funding (i.e., capital structure), investment (i.e., CapEx) and profit distribution (i.e., dividend policy) for all stakeholders (shareholders, government, staff, stock market infrastructure, banks, etc.), who on the basis of signals are able to interpret the further development direction of a company`s market position.

The above mentioned set of managerial decisions on funding, investment and profit distribution is a stakeholders`value-chain (Fig. 1), namely:
- at the stage of funding decisions implementation company raises funding (from internal (equity) and external (loans) sources);

- at the stage of investment decisions implementation, raised funds are used, i.e., transformed into tangible and intangible assets, factors of production that will enable company create sustainable competitive advantages and strengthen its market position, which in turn would create value added for stakeholders (in the form of profit growth);

- at the stage of Profit distribution decisions implementation, that previously created value added is distributed among stakeholders - in a form of dividends, royalties, reinvestments, etc. depending on stakeholders' strategic priorities and their vision of company`s further development.

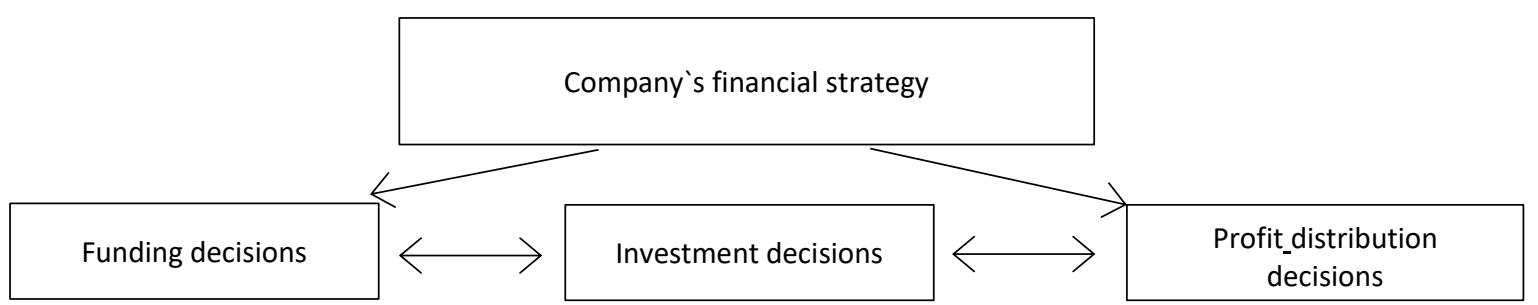

Fig. 1. Company`s financial strategy components

Source: author`s own analysis

Consequently, we propose an analogy between stakeholders' value-chain (in the context of financial strategy) and one of forms of commodities ' circulation by K. Marx, namely Money - Commodity - Money`, where the first phase (Money - Commodity) is a transformation of Money into a Commodity (i.e., borrowed funds' investment into factors of production - in order to produce goods and services), and the second phase (Commodity - Money') - sale of Commodities for an increased amount of Money (i.e., sale of goods and services produced (through investing in factors of production), with subsequent Profit distribution (value added) among stakeholders in the form of dividends, royalties, reinvestments, etc.). "Buy to sell at a higher price" is a form that is characteristic not only of commercial capital, but also of industrial capital. Thus, industrial capital is also Money that is converted into a Commodity and by selling the Commodity is again converted into more Money (Money - Commodity Money '). That increase in the amount of Money may be identified as profit (value added for shareholders), which is generated on the basis of competitive advantages created within a company in the process of raising funding, consequently investing in tangible and intangible assets, and distributing generated profit in an appropriate way.
Thus, we consider it necessary to define company's financial strategy in a broad and narrow sense:

- in a narrow sense, company`s financial strategy is a set of managerial decisions aimed at optimizing capital structure and minimizing its weighted average costs in order to create value for stakeholders;

- in a broad sense, company`s financial strategy is a set of managerial decisions in strategic financial management field concerning funding policy, investment policy and dividend policy, which support sustainable competitive advantages, capital structure optimization, market capitalization growth, as a result, creating stakeholder value added.

Such approach is supported by paper [16], where researchers outline that at present, a vast majority of companies use a set of interrelated functional strategies instead of one general full-scale strategy; each functional strategy in that set is designed for the appropriate organizational level. Company strategy`s hierarchy is the following - with corporate strategy at the top (designed to strengthen company`s market position, increase company's efficiency and profitability and, as a result, create value added for stakeholders, which is expressed in company's market capitalization), and functional strategies at the bottom - subordinated to corporate strategy (responsible for effective strategy formulation and implementation in the relevant areas (i.e., financial 
management, marketing management, operational management, HR management, R\&D management, IT management, etc.)). Each functional strategy has to effectively respond to external and internal environments' challenges, in order to maintain the company functional divisions' competitive advantages [19].

Additional evidence of financial strategy's and corporate strategy's interconnectedness is the need for strategy`s results being measurable; corporate strategy`s success is usually measured by financial indicators turnover and profit, as well as market indicators: achieving the target market share, effective launch of a new product, diversification of a product portfolio, entering a new market segment, entering an export market, etc. Ultimately, company's strategy should communicate to stakeholders in what way, over what period of time and to what extent value added will be created. Thus, company's financial strategy is a part of corporate strategy's hierarchy, which in turn is a part of the contour of financial communication to stakeholders. In particular, strategy`s mechanical development and implementation is not sufficient for successful achievement of company strategy`s ultimate objective, yet company`s strategy must be properly initiated, alligned with stakeholder groups'views, communicated, implemented, revised (if necessary), and evaluated. Company`s strategy developing and implementing process is layered with various nuances, including additional complexity created by the status of a public company, when financial strategy of a public company must be consistent not only with shareholders' expectations, but also with capital market expectations, analysts` and investors 'views.

Argument on interconnectedness of financial strategy, corporate strategy and functional strategies is supported in paper by E. Helfert [9], where it is noted that the basis of successful company's management is development, implementation and maintenance of a stable set of functional strategies, investment goals, operational objectives, funding policy that support and reinforce, not contradict each other. For this reason, financial strategy acts as a mediator, enabling an interaction between functional strategies and corporate strategy. Depending on the direction of company's market position development, financial strategy should balance this direction of market position development, i.e., with aggressive market growth (dynamic market share growth) financial strategy should be conservative (when company's development is financed mainly through equity and improvements in operational efficiency); with a moderate vector of market growth, company`s financial strategy should be aggressive, which would reduce the cost of capital through debt financing, thus gaining additional competitive advantages. In support of this argument, research by A. Rappaport [17] speaks, where factors (both of financial and non-financial nature) affecting shareholders' value added creation are identified, namely: 1 . Sales growth dynamics improved; 2 . EBIT margin increased; 3. CapEx reduced; 4. Turnover improved; 5 . Competitive advantages strengthened; 6 . WACC decrease.

Interconnectedness of financial strategy with corporate strategy is also expressed through funding component of strategic initiatives at all organizational levels. In particular, a study [3] supports this argument, where researchers note that the main source of competitive advantage creating stakeholders' value added is a market asymmetry within which a company operates. Company may increase its market capitalization through creating long-term competitive advantages by selecting and implementing an appropriate competitive strategy. For instance, company may create market entry barriers in the form of a unique product, high-quality service, an effective business model, etc., thus, preventing competitors from entering. In practice, creating and implementing an effective market entry barrier requires significant investment - either through significant marketing costs for new products and marketing support campaigns, or through creation of significant cost benefits achieved by optimizing and upgrading the production base, achieving economies of scale. All that requires effective financial management, focused on long-term results. Argument described above on funding component in forming and implementation any strategy (corporate or functional) is revealed in company's market strategy theory by M. Porter.

Thus, financial strategy, acting as a mediator between levels of corporate strategy and functional strategies, would, firstly, perform its direct task of finding the optimal capital structure, secondly, support and enable implementation of other functional strategies, thirdly, balance various components of corporate strategy. Thus, we conclude that to a large extent "company`s financial strategy" essence may be revealed through its interaction with other areas of company's strategy. All above mentioned is summarized in "Company's financial strategy set" (Fig. 2). 


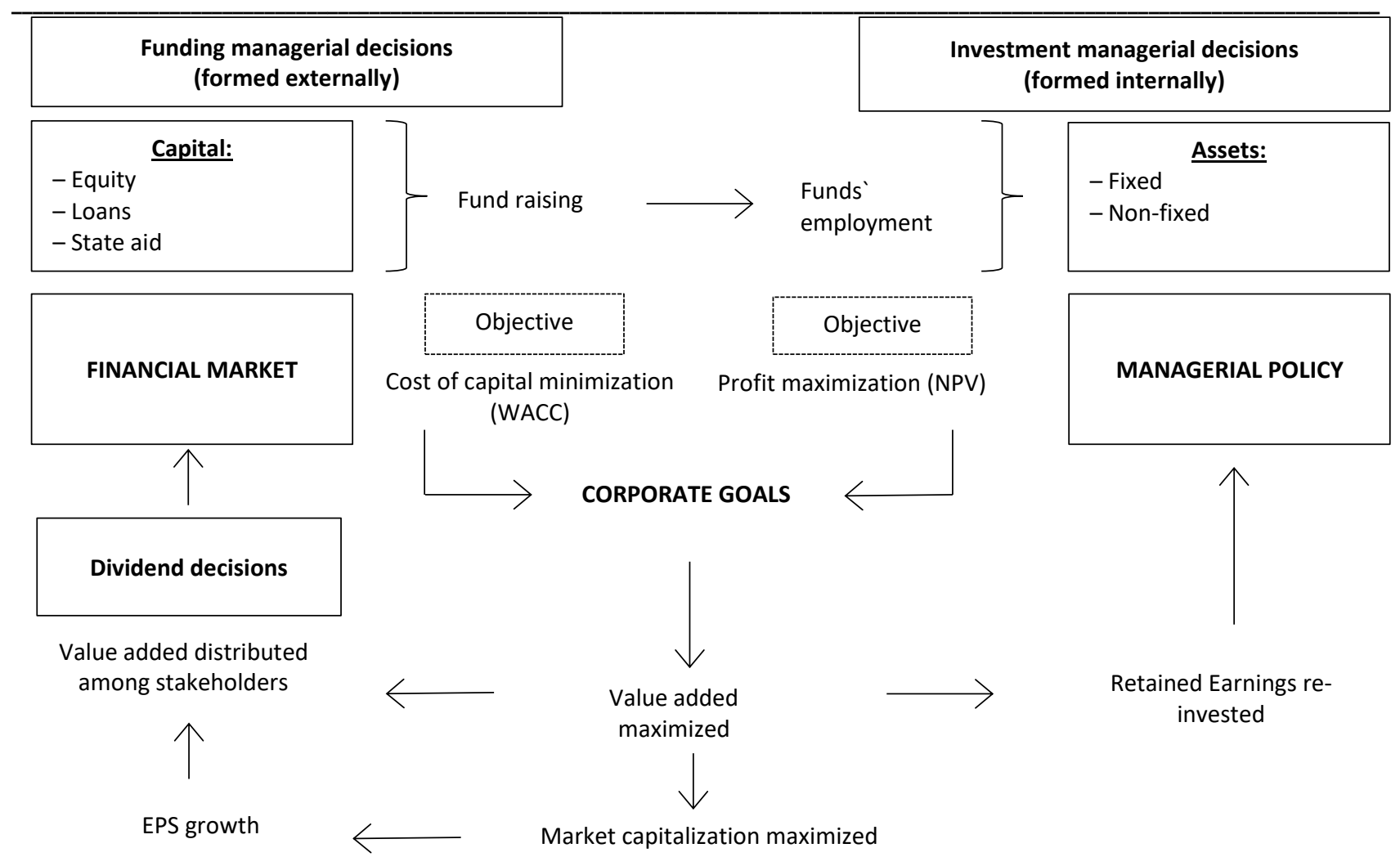

Fig. 2. Company`s financial strategy set

Source: adapted by author from [10].

As company identified its needs in funding, possibilities for raising funds are studied and the best possible option is chosen - in terms of corporate objectives set and stakeholders' preferences. Raised funding has to be with the lowest possible WACC - which in turn contributes to Net Profit margin and further in turn - to stakeholders' value added. Raised funding is then employed in investment activities, i.e. fixed and non-fixed assets, which allow company to maintain and expand its sustainable competitive advantages - thus, protecting value added from erosion. Funds have to be employed with the best possible return, i.e. NPV. Cost of capital minimization (WACC) and Profit maximization (NPV) reflect both sides of stakeholders' value added. Consequently, value added is distributed according to stakeholders' expectations - i.e., dividend policy (portion of Net Profit directed to distribution among shareholders), market capitalization increase (expressed in EPS growth), managerial policy (other portion of Net Profit, namely reinvestment of Retained Earnings). Finally, company's profile with financial market players (shareholders, potential investors, market infrastructure (bankers, rating agencies), state, others) is changed - due to signals sent by a company over course of its financial strategy set.

Conclusions. Financial strategy aims to achieve both general market and specific financial goals. Being a crossdisciplinary concept (i.e., between corporate finance theory and strategic management theory), a balanced financial strategy should take into account interests of all external and internal stakeholders, namely: employees, company`s management, government, creditors, suppliers, local community, consumers, and others. Stakeholders' satisfaction is a major component of a creating value added process in the long run. Creating value for shareholders and other stakeholders is possible as a result of the implementation of financial decisions in the following areas: 1 . determining the optimal capital structure and raising funds at the lowest possible cost; 2 . sound investment policy and efficient allocation of internal resources; 3. dividend policy and Investor Relations. Such a set of objectives entails a need for financial strategy - at its formation and implementation stages - to consider not only company`s financial perspective, but also the overall company`s interaction with both internal and internal environment. Accordingly, development of financial managerial decisions requires considering potential consequences for stakeholder groups (entailing behaviorism aspects, rational and irrational motivations). Thus, an effective and efficient financial strategy is a complex multi-level crossdisciplinary concept that takes into account both narrow tasks (capital structure optimization) and broad tasks (strengthening company's long-term market position, creating added value for stakeholders), which should be based not only on the analysis of retrospective financial and management accounting data, but also consider scientific and practical developments, which, as a result, forms an effective and balanced financial and corporate strategy for a company. 


\section{References:}

1. Ansoff, I. (2007). Strategic Management. London: Palgrave Macmillan UK.

2. Arutjunova, D. (2010). Strateghycheskyj menedzhment. Taganrog: TTY JuFU.

3. Bender, R. \& Ward, K. (2009). Corporate Financial Strategy. Oxford: Butterworth-HeinemannButterworth-Heinemann.

4. Bilyk, M. (2009). Strateghichne upravlinnja ta strateghiji pidpryjemstva. Formuvannja Rynkovykh Vidnosyn v Ukrajini, 4, 143-149.

5. Blank, I. (2009). Finansova strateghija pidpryjemstva. Kyiv: Kyjiv. nac. torgh.-ekon. un-t.

6. Brigham, E. \& Besley, S. (2008). Essentials of Managerial Finance. Mason: Thomson Higher Education.

7. Chandler, A. (2003). Strategy and Structure: Chapters in the History of the American Industrial Enterprise. Fairless Hills, Pennsylvania: Beard Group.

8. Gorytska, N. (2005). Finansova strateghija pidpryjemstva. Finansovyj Dyrektor, 11, 24-32.

9. Helfert, E. (2001). Financial Analysis Tools and Techniques: A Guide for Managers. New York: McGrow-Hill.

10. Hill, R. (2008). Strategic Financial Management. Copenhagen: BoBoCoAe, RAH \& Ventus Publishing ApS.

11. Kay, J. (1996). The Business of Economics. Oxford: Oxford University Press.

12. Myers, S. (1984). Finance Theory and Financial Strategy. Interfaces, 1, 126-137.

13. Naumova, L. (2014). Finansova strateghija ekonomichnogho rozvytku pidpryjemstv. Nauka J Ekonomika, 34, 134-139.

14. Podderjoghin, A. (2000). Finansy pidpryjemstv. Kyiv: KNEU.

15. Polchanov, A. (2011). Ponjattja, skladovi ta zadachi finansovoji strateghiji strakhovoji kompaniji. GISAP.

16. Randoy, T. (2001). Corporate Financial Strategies for Global Competitiveness. European Management Journal, 6, 659-669.

17. Rappaport, A. (1999). Creating Shareholder Value: A Guide For Managers And Investors. New York: Simon and Schuster.

18. Semenov, A. (2012). Klasyfikacija vydiv finansovoji strateghiji pidpryjemstva. Derzhava Ta Reghiony. Serija: Ekonomika Ta Pidpryjemnyctvo, 1, 163-170.

19. Shahmansuri, E. (2013). Survey of Financial Strategies in Corporations. Universal Journal of Management and Social Sciences, 9, 7-20.

Ця робота ліцензована Creative Commons Attribution 4.0 International License 